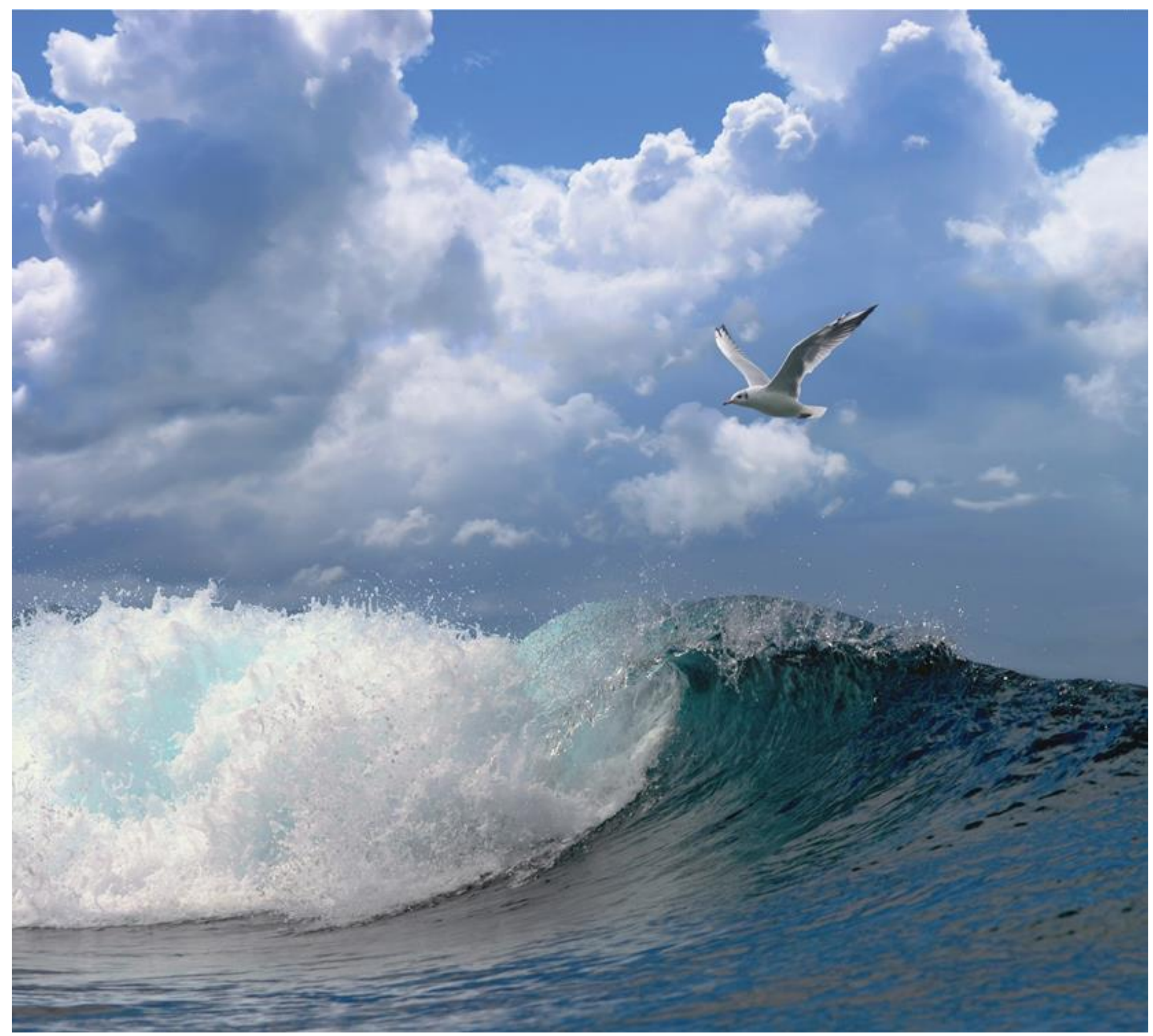

\title{
Monitoring cod catches of the Dutch demersal fleet in 2016
}




\section{Monitoring cod catches of the Dutch demersal fleet in 2016}

Author(s): $\quad$ R. van Hal, M.A.M. Machiels

Publication date: 25 July 2017

This research project was carried out by Wageningen Marine Research at the request of and with funding from the Ministry of Economic Affairs for the purposes of Policy Support Research Theme

'Verduurzaming Visserij' (project no. BO-20-010-002).

Wageningen Marine Research

IJmuiden, July 2017

Wageningen Marine Research report C056/17 
R. van Hal, M.A.M. Machiels. Monitoring cod catches of the Dutch demersal fleet in 2016. Wageningen, Wageningen Marine Research (University \& Research centre), Wageningen Marine Research report C056/17. 29 pages.

Date:

25 July 2017

Client: $\quad$ Ministry of Economic Affairs

Attn.: M.C. Kersbergen

Postbus 20401

2500 EK Den Haag

BO-20-010-002

This report can be downloaded, paper copies will not be forwarded:

https://doi.org/10.18174/420060

Wageningen Marine Research is ISO 9001:2008 certified.

(C) 2017 Wageningen Marine Research Wageningen UR

Wageningen Marine Research The Management of Wageningen Marine Research is not responsible for resulting institute of Stichting Wageningen damage, as well as for damage resulting from the application of results or Research is registered in the Dutch research obtained by Wageningen Marine Research, its clients or any claims traderecord nr. 09098104, related to the application of information found within its research. This report BTW nr. NL 806511618 has been made on the request of the client and is wholly the client's property. This report may not be reproduced and/or published partially or in its entirety without the express written consent of the client. 


\section{Contents}

Samenvatting

Summary

1 Introduction

1.1 Monitoring obligations

6

1.2 Differentiation within gear groups

2 Assignment

$3 \quad$ Materials and Methods $\quad 9$

3.1 Logbook data $\quad 9$

$\begin{array}{lll}3.2 & \text { VMS data } & 9\end{array}$

3.3 Comparison of Logbook and VMS data 9

3.4 Pulse list $\quad 9$

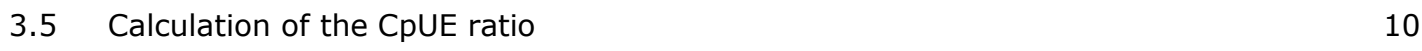

4 Results $\quad 11$

4.1 Overall activity and landings $\quad 11$

$\begin{array}{lll}4.2 & \text { Seasonality } & 15\end{array}$

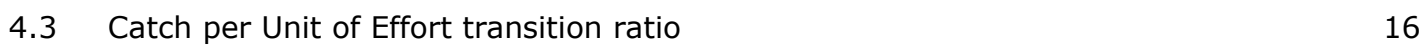
$\begin{array}{lll}\text { 4.3.1 LPUE } & 16\end{array}$

$\begin{array}{lll}\text { 4.3.2 CPUE } & 17\end{array}$

$\begin{array}{ll}4.4 & \text { Percentage of cod avoidance trips } \\ & 4.4 .18\end{array}$

\begin{tabular}{ll}
4.4 .1 & Landings \\
\hline & 18
\end{tabular}

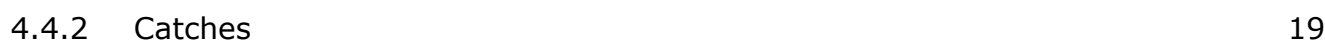

4.5 Comparison with previous years 19

5 Discussion $\quad 21$

6 Conclusions $\quad 22$

$\begin{array}{llr}7 & \text { Quality Assurance } & 23\end{array}$

$\begin{array}{lr}\text { References } & 24\end{array}$

$\begin{array}{lr}\text { Justification } & 25\end{array}$

$\begin{array}{lr}\text { Appendix A The EU Cod Recovery Plan } & 26\end{array}$

$\begin{array}{ll}\text { Appendix B The Dutch Cod Avoidance Plan } & 27\end{array}$

$\begin{array}{ll}\text { Appendix C Extended Materials and Methods } & 28\end{array}$

$\begin{array}{ll}\text { Data pre-processing } & 28\end{array}$

$\begin{array}{lr}\text { Link VMS and logbook data } & 28\end{array}$

$\begin{array}{ll}\text { Spatial distribution } & 28\end{array}$ 


\section{Samenvatting}

In dit rapport worden de resultaten van het kabeljauwmonitoringsprogramma 2016 gepresenteerd. Dit onderzoek is uitgevoerd in opdracht van het Nederlandse Ministerie van Economische Zaken, binnen het EZ-programma Beleidsondersteunend Onderzoek. Kabeljauwvangsten van de schepen in de vlootsegmenten BT2 (boomkor en pulskor) en TR (bordenvisserij en flyshooters) moeten jaarlijks gemonitord worden, in verband met de Nederlandse implementatie van het Europese kabeljauwherstelplan. Het Europese kabeljauwherstelplan beperkt visserijinspanning voor Europese vloten die kabeljauw vangen. Visserijinspanning wordt toegewezen aan verschillende tuigcategorieën op basis van historische vangsten. Visserijinspanning in een bepaalde categorie kan overgeheveld worden naar een andere categorie, maar wel volgens een ruilfactor. In Nederland wordt visserijinspanning jaarlijks overgeheveld van het BT2-vlootsegment naar het TR-vlootsegment volgens de ruilfactor van 1:3 (BT:TR) kilowattdagen in plaats van de Europees vastgestelde ruilfactor van $1: 16$. De reden hiervoor is dat een conversiefactor van $1: 3$ meer overeenkomt met de daadwerkelijke Nederlandse kabeljauwvangsten in de tuigcategorieën. Om de nationaal gehanteerde ruilfactor te onderbouwen heeft de Nederlandse overheid de verplichting om jaarlijks de kabeljauwvangst per eenheid van visserijinspanning (CpUE) van de schepen in deze tuigcategorieën te rapporteren aan de Europese Commissie.

In dit rapport wordt een overzicht gepresenteerd van de visserijactiviteit, de kabeljauwvangsten en de kabeljauwaanlandingen per eenheid visserijinspanning van de BT2 en TR-vlootsegmenten gedurende het jaar 2016. Daarnaast is de kabeljauwvangst-per-eenheid-inspanningsratio van de BT2 aan de ene kant en de TR1C plus de TR2 vlootsegmenten aan de andere berekend en het percentage kabeljauwvermijdingsreizen - visreizen waarbij 5\% kabeljauw of minder is gevangen - in de TRvlootsegmenten.

Het TR-vlootsegment heeft gemiddeld een hogere kabeljauwvangst per eenheid inspanning dan het BT-vlootsegment. Wanneer het kabeljauwgerichte TR1AB vlootsegment niet in beschouwing wordt genomen, ligt de kabeljauwvangst-per-eenheid-inspanningsratio (TR1C+TR2): BT2 in 2016 tussen de 4.2:1 en de 5.7:1. Bij de eerstgenoemde ratio zijn de schepen die deelnemen aan het CCTV programma niet meegenomen en is uitgegaan van minimum kabeljauwdiscardsschattingen van het Scientific, Technical and Economic Committee for Fisheries (STECF) en bij de laatstgenoemde is uitgegaan van maximum schattingen inclusief de CCTV schepen. Wanneer uitgegaan wordt van gemiddelde kabeljauwdiscardsschattingen van alle schepen is de ratio: 5.1:1.

Het percentage kabeljauwvermijdingsreizen, visreizen waarbij 5\% kabeljauw of minder wordt gevangen, in de TR1C en de TR2 vloot was 94\% en 96\% respectievelijk. Deze percentages zijn gebaseerd op gemiddelde STECF schattingen van kabeljauwdiscards. Wanneer het percentage kabeljauwvermijdingsreizen wordt berekend op basis van minimum of maximum kabeljauwdiscardsschattingen van STECF, dan verschilt het berekende percentage met niet meer dan 2 of 3 procent van het percentage op basis van de gemiddelde schattingen. 


\section{Summary}

This report presents the results of the cod monitoring program 2016. The research was commissioned by the Dutch Ministry of Economic Affairs within the EZ-program Beleidsondersteunend Onderzoek. Cod catches of the vessels in the fleet segments BT2 (beam trawl and pulse trawl) and TR (otter trawls and seines) need to be monitored yearly, due to the Dutch implementation of the European cod recovery plan. The European cod recovery plan restricts the fishing effort of European fleets catching cod. Fishing effort, based on historical track records, is allocated to different gear groups. Fishing effort can be transferred between gear groups by use of conversion factors. In the Netherlands fishing effort is transferred yearly from the BT2 gear group to the TR group, based on a national conversion factor of $1: 3$ (BT:TR) kWdays instead of the European conversion factor of $1: 16$. This is because the cod catches in the Dutch TR fleet are not as high as the European conversion factor implies. In order to substantiate for the national conversion factor, the Dutch government is obliged to report cod catches per unit of effort (CpUE) of the vessels in these gear groups to the European Commission.

An overview is provided of the fishing activity, the cod landings and the cod landings per unit of effort of the various gear categories in the BT2 and the TR fleet segments during the year 2016. First the cod Catch per Unit of Effort (CPUE) transition ratio between the BT2 on the one hand and the TR1C plus TR2 fleet segments on the other hand was calculated. And secondly the percentage of cod avoidance trips - trips during which $5 \%$ or less cod was caught - in the TR-fleet were calculated.

The TR fleet has a higher cod CpUE on average than the BT fleet. When the cod targeted fisheries (TR1AB) are not taken into account, the CpUE effort transition ratio (TR1C+TR2): BT2 of 2016 lies between $4.2: 1$ and 5.7:1, depending on whether the ratio is calculated on the basis of minimum or maximum cod discards estimation by the Scientific, Technical and Economic Committee for Fisheries (STECF) respectively whereby in the minimum calculation the vessels participating in the CCTV program are excluded. Based on average discards estimations including all vessels, the ratio is 5.1:1.

The percentage of cod avoidance trips, fishing trips with $5 \%$ cod or less in the total catches, in the TR1C and the TR2 fleets were $94 \%$ and $96 \%$ in 2016 respectively. These percentages are based on average STECF cod discards estimations. When minimum or maximum discards estimations are used, the calculated percentages of cod avoidance trips does not vary more than 2 or $3 \%$ from the percentage based on average estimations. 


\section{Introduction}

\subsection{Monitoring obligations}

This report presents the results of the Dutch Cod Monitoring Program in 2016. The monitoring program was part of the Cod Avoidance Plan developed by the Dutch Government together with the Dutch fishing sector. The aim of this monitoring program was to provide information on the Catch per Unit Effort (CPUE) in the BT and the TR fleet (bottom trawls and otter trawls/seines). This monitoring was needed in order to calculate a conversion factor for the transfer of effort from the BT to the TR fleet. The transition of $\mathrm{kW}$-days between fleet segments was regulated by the cod recovery plan (EC 423/2004 and EC 1342/2008) and depended on the yearly CpUE ratio of cod between the respective fleet segments. The conversion factor set by the EU commission was $1: 16$; meaning that 16 days of the BT2 fleet could be converted to 1 TR-day. See Appendices A and B for a further explanation of the European cod recovery plan and the Dutch Cod Avoidance Plan respectively.

In the Dutch Cod Avoidance Plan, the Dutch Government distinguished between otter trawls and seines that were cod-directed (TR1A and TR1B) and those for which cod was bycatch (i.e. TR1C and TR2) to determine a new conversion factor. The kW-days transition only applied to the TR1C and TR2 gear groups (Table 1). Other gears used by Dutch fishermen, such as by shrimp fisheries and gill netters are not taken into consideration in this report, as the monitoring obligation applied to the gears for which a national conversion factor for the transfer of effort was used. For the kW-days transition between the BT and the TR gears for which cod was bycatch, a conversion factor of 1:3 was used in the Netherlands. This was different than stated in the European Cod Recovery Plan and therefore the ratio needed to be substantiated for.

Table 1. Definitions of the fleet segments used in this report.

\begin{tabular}{|c|c|c|c|}
\hline Fleet definition & Geartype & Meshsize (mm) & Assumed target species \\
\hline TR1A and TR1B & $\begin{array}{l}\text { Otter/pair trawlers and } \\
\text { seines }\end{array}$ & $>120$ & Cod \\
\hline TR1C & $\begin{array}{c}\text { Otter/pair trawlers and } \\
\text { seines }\end{array}$ & $100-119$ & Plaice \\
\hline TR2 & $\begin{array}{c}\text { Otter/pair trawlers and } \\
\text { seines }\end{array}$ & $70-99$ & Plaice/Nephrops \\
\hline BT2 & Beam trawlers & $70-119$ & Plaice/Sole \\
\hline BT1 & Beam trawlers & $>120$ & Sole \\
\hline
\end{tabular}

In 2011, Wageningen Marine Research was requested to start a monitoring program for cod catches in the TR fleet. The program consisted of an extended analysis of self-reported cod catch data (both landings and discards) in combination with the regular Data Collection Framework (DCF) discard monitoring program, an additional observer program, and the CCTV-project in TR-fisheries (see Kraan et al., 2013, 2014). With experience of the first monitoring reports, the ministry of Economic Affairs and Wageningen Marine Research drew the conclusion that monitoring cod discards via the selfreporting scheme asked for a disproportionately high effort of the TR-skippers and resulted in large and costly data-streams while discards were hardly affecting CpUE rates (Ministry of Economic Affairs, 2014). Therefore, it was agreed to do the analysis based on the EU-logbook (hereafter logbook) data in combination with VMS-data, which are readily available. Based on the logbook and VMS-data, an accurate estimate of the LpUE (Landings per Unit Effort) could be calculated for all four fleets. With these, the LpUE-ratio between TR (with cod as bycatch) and BT2 could be determined. As the EU requires a CpUE-ratio (Catch per Unit Effort), discard rates of the Scientific, Technical and Economic Committee for Fisheries (STECF) are used to calculate CpUE-ratios.

In addition to the CpuE ratio between the BT and the TR-fleet, the percentage of trips in the TR-fleet with less than $5 \%$ cod catches in relation to the total catch needs to be monitored. Trips with less than 
$5 \%$ cod catches are referred to as 'cod avoidance trips'. Through cod avoidance trips, effort reductions of the European Cod Recovery Plan can be undone and it contributes to earning the - for the Dutch TR-fleet - more favourable conversion factor.

\subsection{Differentiation within gear groups}

The kW-days transition is calculated by the ratio between the cod CpUEs of BT2 and TR (TR1C \& TR2). However, these fleet segments are composed of different types of gears, with gear-specific regulations. For instance, within the BT2 fleet, a distinction can be made based on the vessel's engine power. Bottom trawl vessels with an engine power of $<300 \mathrm{hp}$ (so-called Eurocutters) are allowed to fish in a closed area ("Plaice-box") and the Dutch 12-mile Exclusive Economic Zone, while bottom trawl vessels with an engine power of $>300 \mathrm{hp}$ are not. Another important distinction to make is between traditional beam trawlers and pulse trawlers. Although both metiers are classified as BT2, the gears are operated differently and have another impact. For instance other areas can be fished and average fishing speed is lower for pulse vessels than for traditional beam trawl vessels, both of which might affect cod catches and thus CpUE. A third differentiation is that within the TR fleet some vessels use otter trawl gear while others use the flyshoot technique. As the flyshoot technique enables fishermen to fish without dragging the net through the water, the engine power can be reduced. As fisheries effort measured in kWdays is reduced subsequently, this affects cod CpUE as cod catches are divided by the fisheries effort. Differentiations like these might impact cod CpUE and therefore these aspects (specific gear types, gear usage, but also spatial distribution and seasonality) have been taken into account. In total 10 gear types are distinguished in this report (Table 2).

Table 2. Definitions of the gear types used in this report.

\begin{tabular}{|c|c|c|c|c|c|}
\hline & Gear definition & $\begin{array}{c}\text { Fleet } \\
\text { segment }\end{array}$ & Description & $\begin{array}{c}\text { Meshsize } \\
(\mathrm{mm})\end{array}$ & Assumed target species \\
\hline 1 & Beam_trad* & BT2 & $\begin{array}{l}\text { Engine power }>300 \mathrm{hp} \text {, } \\
\text { traditional beam trawl }\end{array}$ & $70-119$ & Plaice/Sole \\
\hline 2 & Beam_puls* & BT2 & $\begin{array}{c}\text { Engine power }>300 \mathrm{hp}, \\
\text { pulse gear }\end{array}$ & $70-119$ & Plaice/Sole \\
\hline 3 & Euro_trad* & BT2 & $\begin{array}{l}\text { Engine power }<300 \mathrm{hp} \text {, } \\
\text { traditional beam trawl }\end{array}$ & $70-119$ & Plaice/Sole \\
\hline 4 & Euro_puls* & BT2 & $\begin{array}{c}\text { Engine power }<300 \mathrm{hp} \text {, } \\
\text { pulse gear }\end{array}$ & $70-119$ & Plaice/Sole \\
\hline 5 & Otter_70-99 & TR2 & Otter/pair trawler; twinrig & $70-99$ & Plaice/Nephrops \\
\hline 6 & Otter_100-119 & TR1C & Otter/pair trawler; twinrig & $100-119$ & Plaice \\
\hline 7 & Otter_120+ & TR1AB & Otter/pair trawler; twinrig & $>120$ & Cod \\
\hline 8 & Fly_70-99 & TR2 & Flyshooter & $70-99$ & Various species \\
\hline 9 & Fly_100-119 & TR1C & Flyshooter & $100-119$ & Various species \\
\hline 10 & Fly_120+ & TR1AB & Flyshooter & $>120$ & Various species \\
\hline
\end{tabular}

* These gear types may comprise more subgear-types, for instance the sumwing. However, the expectation is that the catchabitlity of cod for these subgear-types is similar. 


\section{Assignment}

The Ministry of Economic Affairs asked Wageningen Marine Research in 2014 to perform an analysis on the reported cod landings in the Dutch TR and BT2 fleets with the aim to:

i. estimate the CpUE (in kilos of cod caught per days at sea * engine power (kWdays)) per TR fleet segment;

ii. estimate the CPUE (in kilos of cod caught per days at sea * engine power (kWdays)) per BT fleet segment;

iii. compare the estimated TR-CpUEs with the BT2-CPUE and BT-CPUE;

iv. calculate the percentage of trips in the TR fleet (TR2, TR1C), with less than $5 \%$ cod catches in relation to the total catch (this is referred to as 'cod avoiding fishing trips' in the Dutch Cod Avoidance Plan). 


\section{$3 \quad$ Materials and Methods}

In this section, the data sources, the analysis and the final output are described. See "Appendix C. Extended Material and Methods" for a detailed description of the method to link VMS and logbook data.

\subsection{Logbook data}

All fishermen are obliged to report their activities on a daily (24 hours) basis. This includes location, gear used, vessel characteristics and estimated landing quantities (in $\mathrm{kg}$ ). These quantities are an estimation and therefore deviate from auction data. Moreover, fishermen do not have to report catches for species with a trip-total quantity below $50 \mathrm{~kg}$. As cod is a by-catch species, trips with cod landings lower than $50 \mathrm{~kg}$ can be expected. Therefore, the cod catches in this report are an underestimation of the total catches. Second, fishermen report all landings and vessel characteristics online and the data are immediately imported in the database of the Dutch Government. The logbook data cannot be validated or checked by Wageningen Marine Research on correctness of the data. Therefore, records with a type-error in the gear description will not be recognised as 'wrong', but will wrongly be taken into consideration.

\subsection{VMS data}

All vessels over 12 meters are obliged to participate in the Vessel Monitoring System (VMS). This system sends an update to a satellite every two hours, containing time and date, position, speed and name of the vessel. All these records are registered by the Dutch Government. Wageningen Marine Research has permission to work with these data.

\subsection{Comparison of Logbook and VMS data}

The logbook data do not always completely match with the VMS data, because sometimes the trip numbers in both data sets do not match. When no matching trip number can be found between the two data sets, the logbook data are not included in the VMS database. For that reason the landings recorded in the logbook database may be some percentage higher than the landings recorded in the VMS database. The reasons for the mismatch is up till now unknown but may include incorrect registration, deficient VMS equipment or incorrect data transmission. In this report the maps that demonstrate spatial distribution are based on the VMS database. The tables displaying landings and fishing activity are based on logbook data. The reason for using logbook data when no spatial information is needed is that this database includes fewer assumptions than the VMS database. The consequence of this methodological choice is that landings and effort displayed in tables may deviate slightly from landings and effort displayed in maps.

\subsection{Pulse list}

Gear specifics, like net type, mesh size and vessel engine power are registered in the logbooks. However, the logbook does not contain information about the use of pulse gear. Therefore, Wageningen Marine Research has created a list of all vessels in the Dutch demersal fleet with a licence to fish with pulse gear. For vessels with a license for pulse fishing, the date of actual conversion to / from pulse gear is registered as well. This list is based on knowledge from the ministry of Economic Affairs, the Dutch Cooperative Fisheries Organisation (CVO) and personal contact with fishermen and 
is updated regularly. Based on this list, all logbook and VMS data of beam trawl trips are classified "pulse" or "traditional".

\subsection{Calculation of the CpUE ratio}

The yearly CpUE ratio between the BT2 and the TR1C and the TR2 fleet is calculated through the following formula:

$$
\left(\frac{(\text { Cod catches TR1C }+T R 2)}{(\text { Fishing activity } T R 1 C+T R 2)}\right) /\left(\frac{\text { Cod catches BT2 }}{\text { Fishing activity } B T 2}\right)
$$

The calculations are done with the cod catches and activities of all the RT1C, TR2 and BT2 vessels as was done for 2014 and 2015 (Reijden et al, 2016 and Trapman \& Machiels, 2016a), but is also done on the catches and activities excluding the 12 vessels participating in the CCTV program. 


\section{$4 \quad$ Results}

In the results section, spatial distributions of the fishing activity and cod landings of total fleet and the 10 gear types separately are presented for 2016. In addition the fishing activity and the cod landings of the total fleet are presented per month. Landings- and effort values are higher than those presented in the quarterly report of Q1 (Trapman \& Machiels, 2016b) because the database was not fully synchronized at the time of data extraction for the quarterly report. Eventually, the TR1C+TR2:BT2 CpUE ratio and the percentage of fishing trips with $<5 \%$ cod catches of the TR-fleet segments are given.

\subsection{Overall activity and landings}

In 2016, fishing activity of all demersal fisheries together was just over 21 million kW-days (Figure 1). This was somewhat lower in 2016 compared to 2015 ( +0.5 million kW-days) and 2014 ( +0.1 million $\mathrm{kW}$-days). The fishing activity was dominated by the larger beam trawl vessels, consisting of pulse gears ( $\sim 13$ million kW-days) and traditional tickler chains ( 4.8 million kW-days) (Figure 2 ). The beam trawl activity has decreased compared to 2015 ( 0.6 million $\mathrm{kW}$-days) but is slightly higher compared to 2014 ( 0.3 million $\mathrm{kW}$-days). The traditional beam trawl decreased to only $4.8 \mathrm{million} \mathrm{kW}$ days (2.5 million less than in 2015), while the pulse trawl activity further increased to 13.0 million kW-days (2.0 million more than in 2015) (see Reijden et al, 2016 and Trapman \& Machiels, 2016a).

Fishing activity (in *1000 kW-days) in 2016

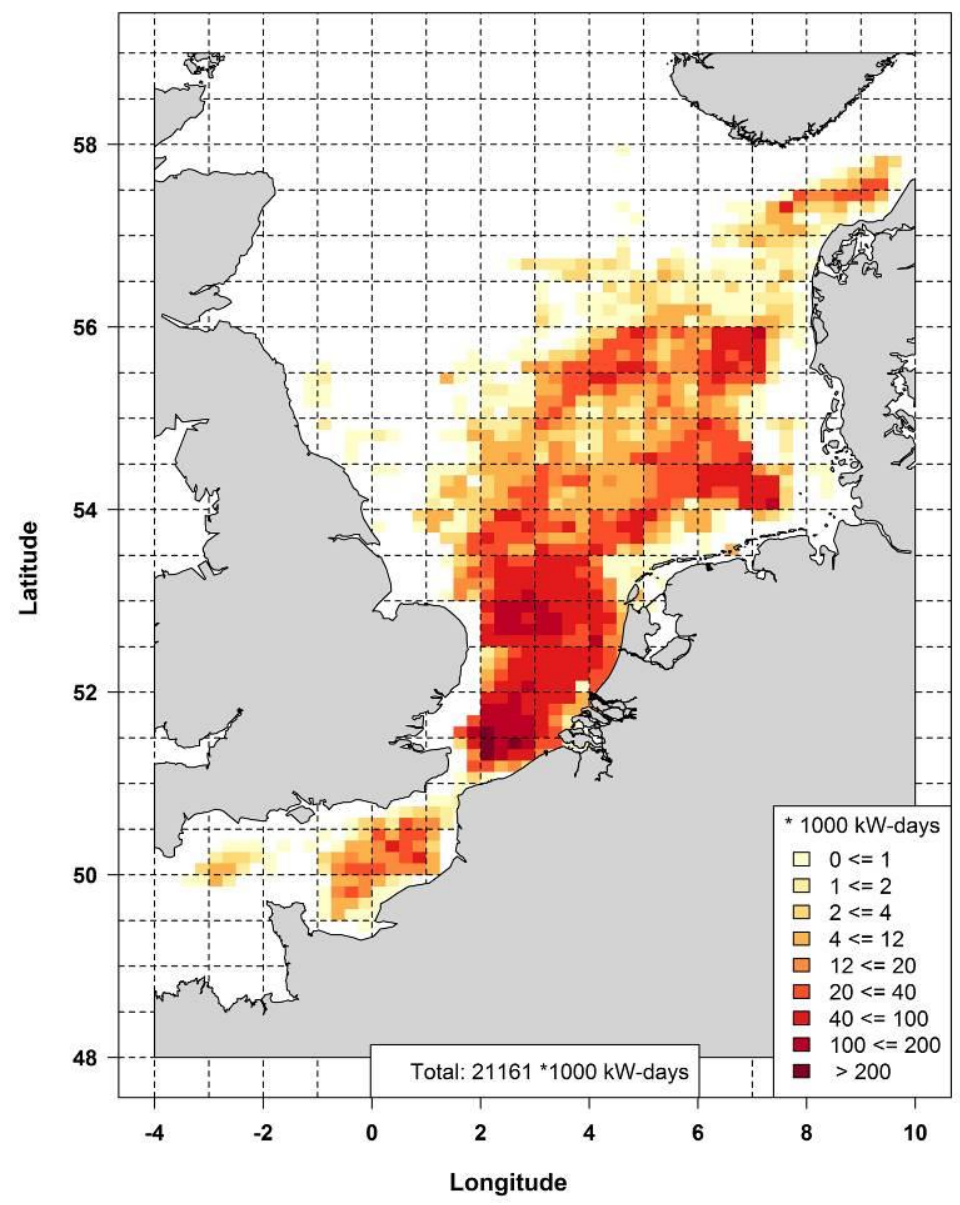

Figure 1. Fishing activity (in *1000 kW-days) for the Dutch demersal fleet for which the Dutch Cod Avoidance Plan was in place in 2016. 

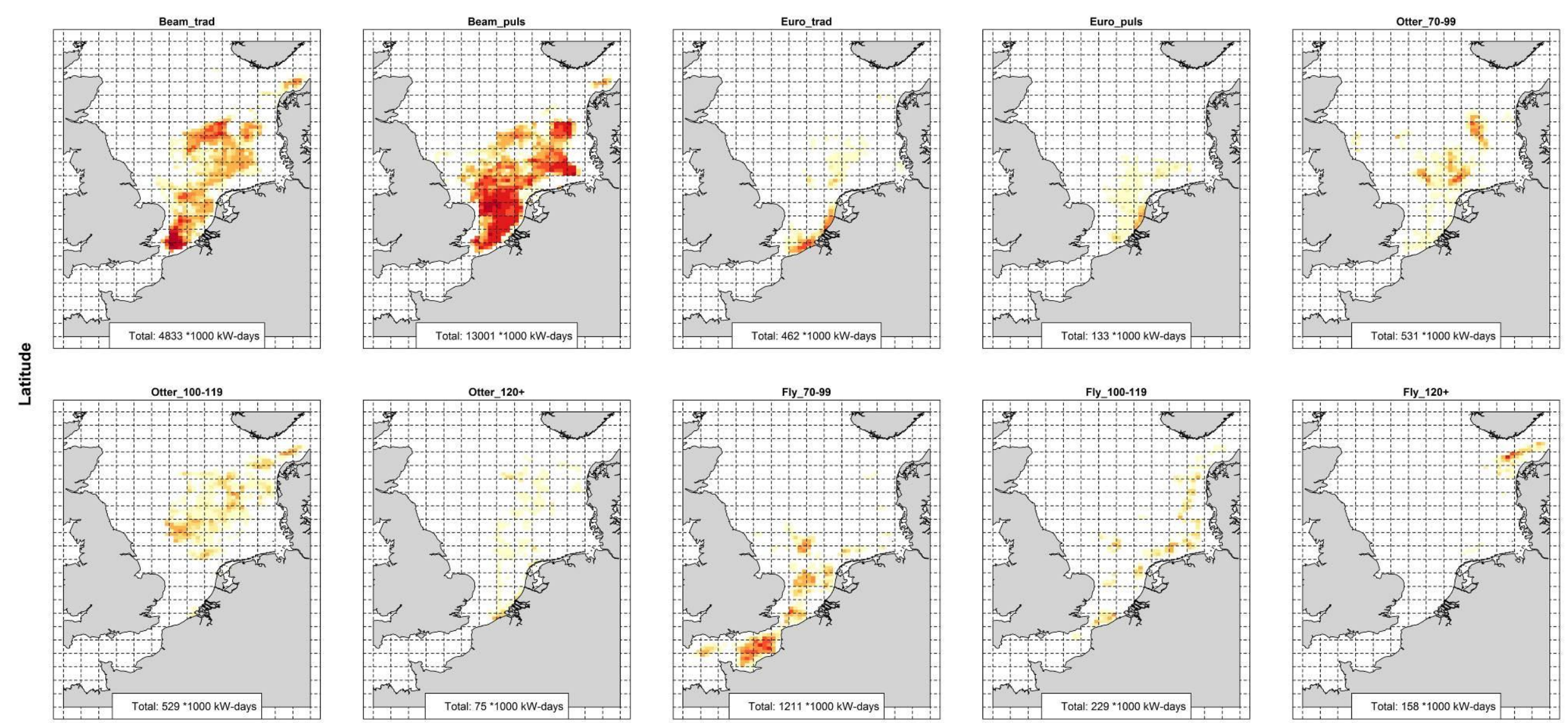

Figure 2. Fishing activity (in $* 1000 \mathrm{~kW}$-days) for ten demersal fishing gears separately in 2016. Descriptions for the gear types are given in Table 1. Colour index is similar to Figure 1. 
A total of 1226 tonnes cod was caught in all fisheries in 2016 (Figure 3), this is a decrease of 50 tonnes compared to 2015, yet about 50 tonnes more than in 2014. Locations with relative high cod landings were the opening of the Skagerrak, and The Falls (around $51.5^{\circ} \mathrm{N}, 2-3^{\circ} \mathrm{E}$ ). The Cleaver Bank (around $54^{\circ} \mathrm{N}, 3^{\circ} \mathrm{E}$ ) reduced in importance compared to 2015.

\section{Cod landings (in Ton) in 2016}

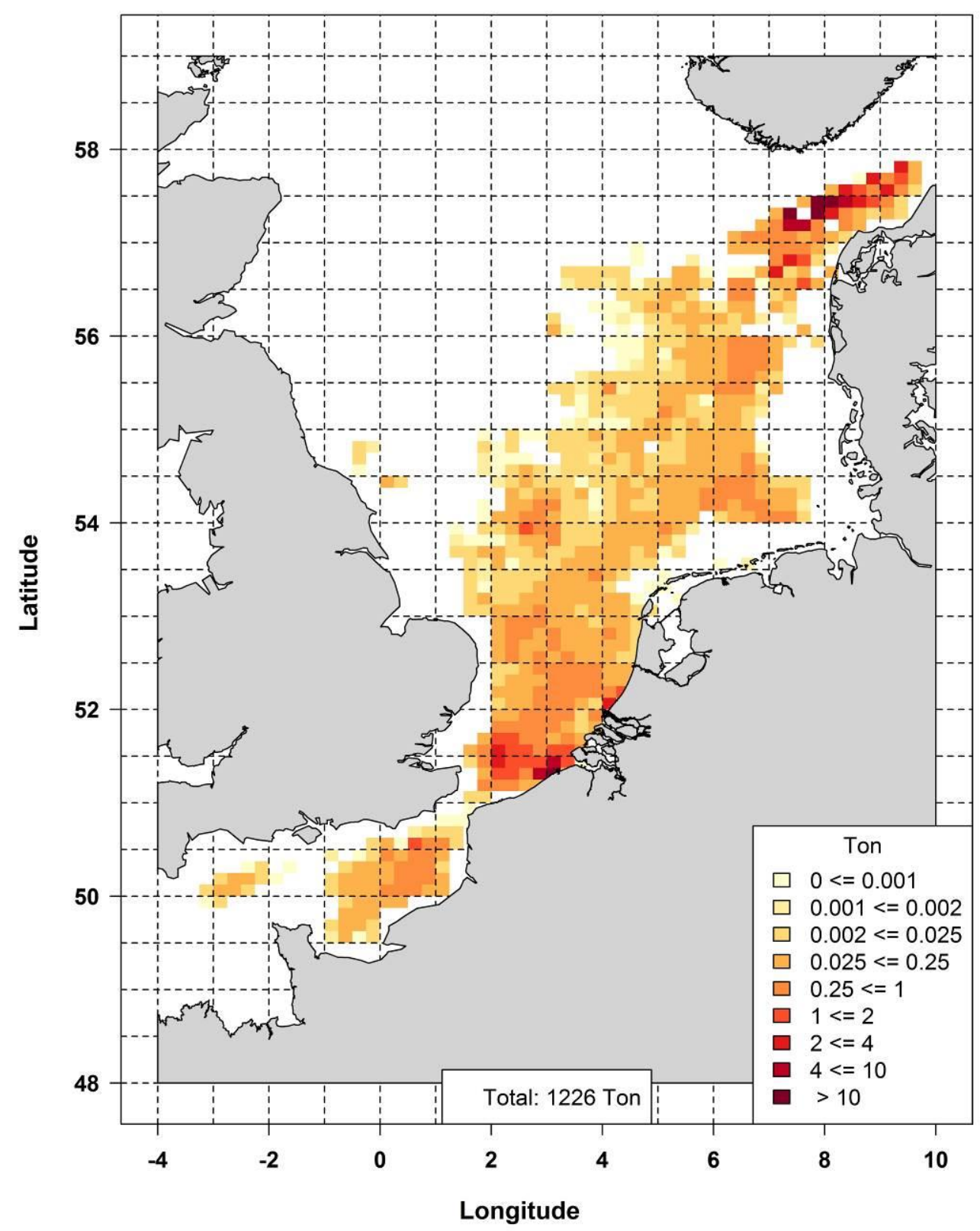

Figure 3. Cod landings (in tonnes) for the Dutch demersal fleet in 2016.

The ten gear types identified in this report differ greatly in cod landings. The landings pattern is similar to the patterns in 2015 and 2014: with the large meshed flyshooters $(>120 \mathrm{~mm})$ landing the majority of the cod (Figure 4). This fleet segment is mainly responsible for the cod landings from the opening of the Skagerrak, and its total cod landings increased from 470 to 631 tonnes. The beam trawlers and the Eurocutters (both pulse and traditional gears) are the main gear types landing cod from The Falls. While the effort of the Beam_Pulse increased the cod landings decreased. 

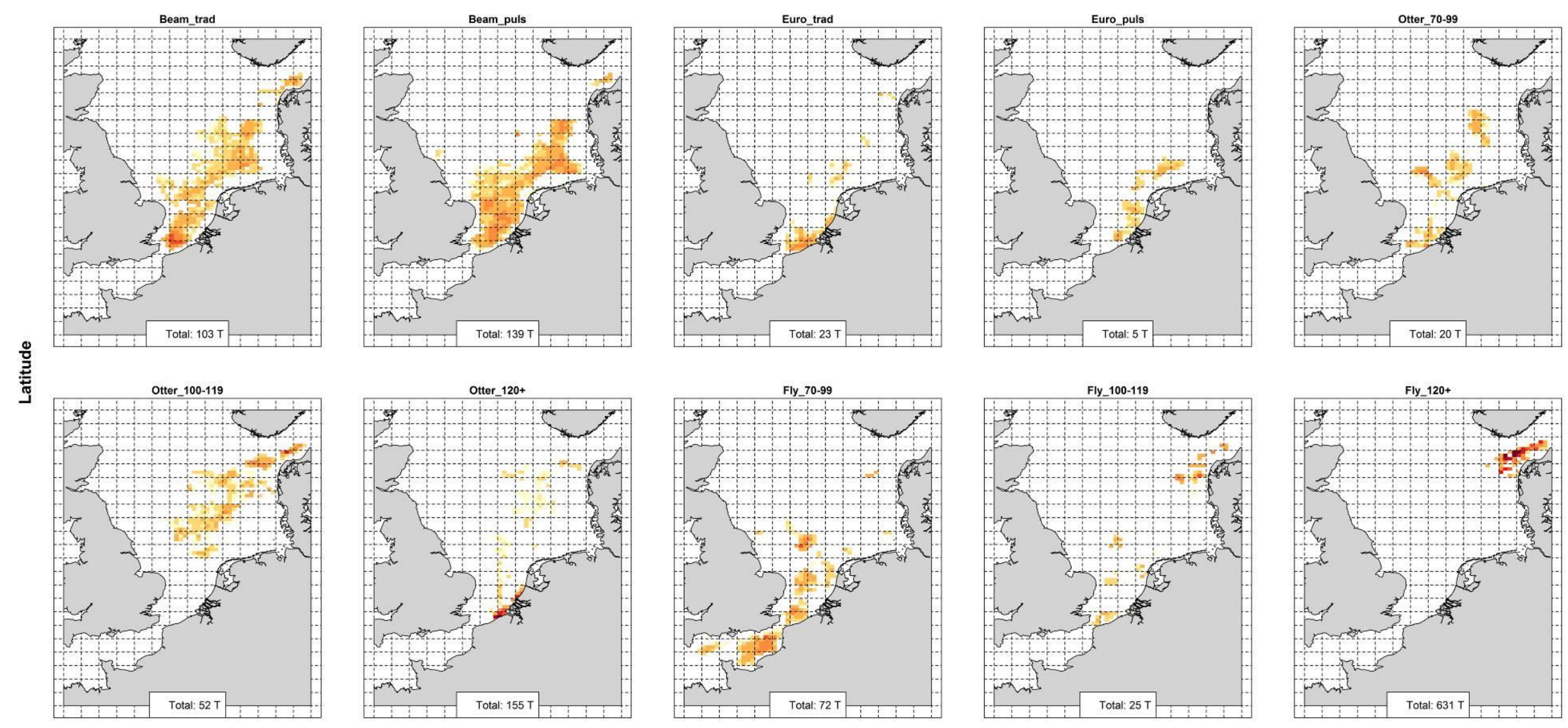

Figure 4. Cod landings (in tonnes) for ten demersal fishing gears separately in 2016. 


\subsection{Seasonality}

Seasonality is a well-known factor in fisheries that should be taken into account when looking at catches, landings and/or fishing behaviour. Seasonality in fisheries is caused by underlying explanatory factors as well as effects, amongst others: changes in fish abundance, fish quality, weather (e.g. wind force and direction), quota, days at sea, and fish prices. Because of these combined factors, no two years, or even months are equal. However, trends in time over the different seasons or different years can be observed. The year report of 2014 (Reijden et al., 2016) describes the trends in fishing activity and cod catches between 2011 and 2014 in the different gear groups more extensively and the general fishing pattern of each gear group. Table 3 lists the fishing activity per fleet segment per month in 2016, table 4 lists the cod landings per fleet segments per month in 2016 and table 5 lists the cod CpUE per fleet segment per month. The cells in table 5 have been filled with colours with the lowest values in green and the highest values in red. The colours have been applied in order to increase the legibility of the table.

Table 3. Fishing activity (*1000 kW-days) in 2016 for the gears separately per month. Values based on the VMS-data.

\begin{tabular}{|c|c|c|c|c|c|c|c|c|c|c|c|c|c|}
\hline & Jan & Feb & Mar & Apr & May & Jun & Jul & Aug & Sep & Oct & Nov & Dec & Mean \\
\hline Beam_trad & 517 & 502 & 545 & 451 & 416 & 295 & 224 & 298 & 376 & 395 & 442 & 372 & 403 \\
\hline Beam_puls & 1101 & 1017 & 1248 & 1019 & 961 & 1062 & 936 & 1069 & 1125 & 1152 & 1255 & 1057 & 1084 \\
\hline Euro_trad & 39 & 41 & 61 & 62 & 63 & 57 & 41 & 29 & 17 & 16 & 12 & 25 & 39 \\
\hline Euro_puls & 13 & 9 & 12 & 10 & 7 & 10 & 8 & 10 & 10 & 16 & 13 & 15 & 11 \\
\hline Otter_70-99 & 26 & 37 & 42 & 40 & 47 & 69 & 54 & 56 & 51 & 40 & 31 & 38 & 44 \\
\hline Otter_100-119 & 5 & 12 & 8 & 36 & 81 & 93 & 80 & 71 & 43 & 54 & 42 & 6 & 44 \\
\hline Otter_120+ & 10 & 4 & 19 & 9 & 5 & 19 & 5 & 3 & 0 & 0 & 0 & 1 & 6 \\
\hline Fly_70-99 & 123 & 126 & 147 & 144 & 77 & 89 & 60 & 53 & 52 & 87 & 130 & 122 & 101 \\
\hline Fly_100-119 & 1 & 0 & 1 & 1 & 29 & 39 & 43 & 59 & 34 & 18 & 5 & 0 & 19 \\
\hline Fly_120+ & 0 & 0 & 0 & 0 & 8 & 12 & 24 & 36 & 46 & 30 & 2 & 0 & 13 \\
\hline Total & 1835 & 1748 & 2083 & 1772 & 1694 & 1745 & 1475 & 1684 & 1754 & 1808 & 1932 & 1636 & 1764 \\
\hline
\end{tabular}

Table 4. Cod landings (kg) in 2016 for the gears separately per month. Values based on the VMS-data.

\begin{tabular}{|c|rrrrrrrrrrrrrrr}
\hline & Jan & Feb & Mar & Apr & May & Jun & Jul & Aug & Sep & Oct & Nov & Dec & Mean \\
\hline Beam_trad & 31500 & 28034 & 12913 & 2511 & 3162 & 1507 & 764 & 1321 & 1835 & 2794 & 8210 & 8249 & $\mathbf{8 5 6 7}$ \\
Beam_puls & 55604 & 44074 & 12572 & 2134 & 4830 & 3464 & 1142 & 653 & 559 & 551 & 4075 & 9749 & $\mathbf{1 1 6 1 7}$ \\
Euro_trad & 8189 & 6257 & 3943 & 2158 & 625 & 182 & 311 & 154 & 45 & 85 & 84 & 1357 & $\mathbf{1 9 4 9}$ \\
Euro_puls & 2840 & 1324 & 780 & 19 & 0 & 0 & 0 & 0 & 0 & 0 & 87 & 250 & $\mathbf{4 4 2}$ \\
Otter_70-99 & 1392 & 4730 & 1765 & 2588 & 2601 & 3188 & 1070 & 9 & 304 & 304 & 533 & 1488 & $\mathbf{1 6 6 4}$ \\
Otter_100-119 & 82 & 2601 & 661 & 1382 & 8114 & 2857 & 674 & 8210 & 7050 & 17864 & 1040 & 1557 & $\mathbf{4 3 4 1}$ \\
Otter_120+ & 17660 & 15698 & 94623 & 24960 & 1550 & 320 & 492 & 0 & 41 & 0 & 0 & 0 & $\mathbf{1 2 9 4 5}$ \\
Fly_70-99 & 13507 & 14140 & 9809 & 7241 & 2151 & 4753 & 4145 & 1637 & 4745 & 6171 & 2110 & 1553 & $\mathbf{5 9 9 7}$ \\
Fly_100-119 & 0 & 0 & 241 & 170 & 1560 & 189 & 83 & 4431 & 4425 & 13581 & 104 & 0 & $\mathbf{2 0 6 5}$ \\
Fly_120+ & 0 & 0 & 0 & 0 & 15252 & 42880 & 96471 & 160957 & 236480 & 79130 & 0 & 0 & $\mathbf{5 2 5 9 8}$ \\
\hline Total & $\mathbf{1 3 0 7 7 4}$ & $\mathbf{1 1 6 8 5 8}$ & $\mathbf{1 3 7 3 0 7}$ & $\mathbf{4 3 1 6 3}$ & $\mathbf{3 9 8 4 5}$ & $\mathbf{5 9 3 4 0}$ & $\mathbf{1 0 5 1 5 2}$ & $\mathbf{1 7 7 3 7 2}$ & $\mathbf{2 5 5 4 8 4}$ & $\mathbf{1 2 0 4 8 0}$ & $\mathbf{1 6 2 4 3}$ & $\mathbf{2 4 2 0 3}$ & $\mathbf{1 0 2 1 8 5}$
\end{tabular}


Table 5. Cod LpUE in (kg/kW-day) in 2016 for the gears separately per month. Table 3 divided by table 4.

\begin{tabular}{|c|c|c|c|c|c|c|c|c|c|c|c|c|c|}
\hline & Jan & Feb & Mar & Apr & May & Jun & Jul & Aug & Sep & Oct & Nov & Dec & Mean \\
\hline Beam_trad & 0.061 & 0.056 & 0.024 & 0.006 & 0.008 & 0.005 & 0.003 & 0.004 & 0.005 & 0.007 & 0.019 & 0.022 & 0.021 \\
\hline Beam_puls & 0.051 & 0.043 & 0.01 & 0.002 & 0.005 & 0.003 & 0.001 & 0.001 & 0 & 0 & 0.003 & 0.009 & 0.011 \\
\hline Euro_trad & 0.21 & 0.153 & 0.065 & 0.035 & 0.01 & 0.003 & 0.008 & 0.005 & 0.003 & 0.005 & 0.007 & 0.054 & 0.05 \\
\hline Euro_puls & 0.218 & 0.147 & 0.065 & 0.002 & 0 & 0 & 0 & 0 & 0 & 0 & 0.007 & 0.017 & 0.04 \\
\hline Otter_70-99 & 0.054 & 0.128 & 0.042 & 0.065 & 0.055 & 0.046 & 0.02 & 0 & 0.006 & 0.008 & 0.017 & 0.039 & 0.038 \\
\hline Otter_100-119 & 0.016 & 0.217 & 0.083 & 0.038 & 0.1 & 0.031 & 0.008 & 0.116 & 0.164 & 0.331 & 0.025 & 0.26 & 0.099 \\
\hline Otter_120+ & 1.766 & 3.925 & 4.98 & 2.773 & 0.31 & 0.017 & 0.098 & 0 & & & & 0 & 2.158 \\
\hline Fly_70-99 & 0.11 & 0.112 & 0.067 & 0.05 & 0.028 & 0.053 & 0.069 & 0.031 & 0.091 & 0.071 & 0.016 & 0.013 & 0.059 \\
\hline Fly_100-119 & 0 & & 0.241 & 0.17 & 0.054 & 0.005 & 0.002 & 0.075 & 0.13 & 0.754 & 0.021 & & 0.109 \\
\hline Fly_120+ & & & & & 1.907 & 3.573 & 4.02 & 4.471 & 5.141 & 2.638 & 0 & & 4.046 \\
\hline Total & 0.071 & 0.067 & 0.066 & 0.024 & 0.024 & 0.034 & 0.071 & 0.105 & 0.146 & 0.067 & 0.008 & 0.015 & 0.058 \\
\hline
\end{tabular}

\subsection{Catch per Unit of Effort transition ratio}

\subsubsection{LPUE}

The European Cod Recovery Plan included effort limitations per fleet segments. It also included a transition factor in kW-days; to transfer kW-days between fleets, based on the cod catches of the fleets. In the Netherlands, a transition factor that deviates from the EU transition factor is used for transferring days at sea from the BT fleet segment to the TR1C and TR2 fleet segments. These fleets are not targeting cod, but catch cod as bycatch. The TR1AB fleet is expected to target cod and is therefore not subject to the adjusted transition factor.

Table 6a shows both fishing effort and cod landings in 2016 per fleet segment per quarter. It also includes the LpUE (Landings per Unit Effort, in $\mathrm{kg} / \mathrm{kW}$-day). Based on these data, a transition factor of 4.6:1 is calculated for (TR1C + TR2): BT2. Table $6 \mathrm{~b}$ shows the same data but here the 12 vessels participating in the CCTV program are excluded. Based on these data a transition factor of 3.9:1 is calculated for (TR1C + TR2): BT2. These vessels are excluded as the fleet that fishes with cameras on board to fully document cod catches are exempted from effort regulations and in addition these vessels receive $30 \%$ cod quota on top of their usual quota.

Table 6a. Total cod landings (in tonnes), fishing effort ( ${ }^{*} 1000 \mathrm{~kW}$-days) and LpUE (kg/kW-day) in 2016 for each fleet segment separately and combined, per quarter and for the total year. Values based on the logbook data.

\begin{tabular}{|c|c|c|c|c|c|c|c|c|c|c|c|c|c|c|c|c|c|}
\hline & \multicolumn{5}{|c|}{ Landings } & \multicolumn{6}{|c|}{ Effort } & \multicolumn{6}{|c|}{ LpUE } \\
\hline & BT1 BT2 & TR1AB & 3 TR1C & TR2 & Total & BT1 & BT2 & TR1AB & TR1C & TR2 & Total & BT1 & BT2 & TR1AB & TR1C & TR2 & Total \\
\hline Q1 & 0214 & 134 & 4 & 48 & 400 & 12 & 5266 & 34 & 36 & 524 & 5872 & 0 & 0.041 & 3.941 & 0.111 & 0.092 & 0.068 \\
\hline Q2 & 21 & 100 & 24 & 20 & 202 & 392 & 4507 & 65 & 271 & 462 & 5697 & 0.094 & 0.005 & 1.538 & 0.089 & 0.043 & 0.035 \\
\hline Q3 & 30 & 491 & 34 & 11 & 573 & 624 & 4254 & 128 & 347 & 322 & 5675 & 0.048 & 0.002 & 3.836 & 0.098 & 0.034 & 0.101 \\
\hline Q4 & 36 & 90 & 23 & 13 & 186 & 176 & 4866 & 35 & 128 & 455 & 5660 & 0.136 & 0.007 & 2.571 & 0.18 & 0.029 & 0.033 \\
\hline 2016 & 91278 & 815 & 85 & 92 & 1361 & 1204 & 18893 & 262 & 782 & 1763 & 22904 & 0.076 & 0.015 & 3.111 & 0.109 & 0.052 & 0.059 \\
\hline
\end{tabular}

Table 6b. Total cod landings (in Tonnes), fishing effort ( $1000 \mathrm{~kW}$-days) and LpUE (kg/kW-day) in 2016 for each fleet segment separately and combined, per quarter and for the total year. Excluding vessels participating in the CCTV program. Values based on the logbook data.

\begin{tabular}{|c|c|c|c|c|c|c|c|c|c|c|c|c|c|c|c|c|c|}
\hline & \multicolumn{5}{|c|}{ Landings } & \multicolumn{6}{|c|}{ Effort } & \multicolumn{6}{|c|}{ LpUE } \\
\hline & BT1 BT2 & TR1AB & 3 TR1C & TR2 & Total & BT1 & BT2 & TR1AB & TR1C & TR2 & Total & BT1 & BT2 & TR1AB & TR1C & TR2 & Total \\
\hline Q1 & 0214 & 51 & 1 & 29 & 295 & 12 & 5265 & 15 & 22 & 300 & 5614 & 0 & 0.041 & 3.4 & 0.045 & 0.097 & 0.053 \\
\hline Q2 & 37 & 12 & 7 & 13 & 89 & 392 & 4498 & 39 & 189 & 314 & 5432 & 0.094 & 0.004 & 0.308 & 0.037 & 0.041 & 0.016 \\
\hline Q3 & 30 & 0 & 18 & 10 & 65 & 624 & 4253 & 16 & 221 & 310 & 5424 & 0.048 & 0.002 & 0 & 0.081 & 0.032 & 0.012 \\
\hline Q4 & $24 \quad 36$ & 4 & 14 & 10 & 88 & 176 & 4866 & 2 & 105 & 279 & 5428 & 0.136 & 0.007 & 2 & 0.133 & 0.036 & 0.016 \\
\hline 2016 & 91277 & 67 & 40 & 62 & 537 & 1204 & 18882 & 72 & 537 & 1203 & 21898 & 0.076 & 0.015 & 0.931 & 0.074 & 0.052 & 0.025 \\
\hline
\end{tabular}




\subsubsection{CpUE}

In the European Cod Recovery Plan, the transition factor is based on total cod catches. Therefore the above calculated LpUE transition factor should be transformed to a CpUE transition factor. The landings from Table 6 should therefore be extrapolated to include cod discards as well. As no monitoring program is currently available in the Netherlands to estimate accurate cod discard rates in all the fleet segments, a range of cod discard estimates is used based on STECF data between 2010 and 2014. Then, CpUE and the ratio between CPUE for the different fleet segments can be calculated. Table 7 presents a time series between 2010 and 2015 of the cod discard fraction of the total cod landings based on STECF data. Based on analysis of the time series of cod discards (table 7), table 8 demonstrates the average cod discard fraction of total cod catches and a low and a high estimation. The low and the high estimation are calculated as the $90 \%$ confidence interval of the mean, meaning that $5 \%$ of the observed discard estimates are lower than the low estimate and $5 \%$ of the observations are higher than the high estimate.

Table 7. Time series between 2010 and 2015 of cod discard fraction of total cod landings based on STECF data.

\begin{tabular}{c|cccc|}
\hline Year & BT1 & BT2 & TR1 & TR2 \\
\hline 2010 & 0 & 0.13 & 0.1 & 0.58 \\
2011 & 0 & 0.08 & 0.03 & 0.62 \\
2012 & 0 & 0.15 & 0.08 & 0.33 \\
2013 & 0 & 0.13 & 0.24 & 0.21 \\
2014 & 0 & 0.19 & 0.03 & 0.65 \\
2015 & 0.05 & 0.09 & 0.09 & 0.39 \\
MEAN & 0.01 & 0.13 & 0.09 & 0.42 \\
SD & 0.02 & 0.04 & 0.07 & 0.16 \\
\cline { 2 - 5 } & & & &
\end{tabular}

Table 8. Estimation range of cod discards faction of total cod catches based on STECF data, including the average estimation and a low and a high estimation.

\begin{tabular}{|c|c|c|c|}
\hline & Disc\%Average & low & high \\
\hline BT1 & 0.007 & 0.000 & 0.024 \\
\hline BT2 & 0.115 & 0.085 & 0.145 \\
\hline TR1C & 0.080 & 0.018 & 0.142 \\
\hline TR2 & 0.285 & 0.194 & 0.376 \\
\hline
\end{tabular}

Based on the estimated cod discard ranges (table 8), table 9a shows the estimated ranges of the total cod catch and the ranges of the CpUE in the different fleet segments. Based on these estimations of the cod catch:

- $\quad$ Based on the minimum CpUE estimations, a minimum transition factor of 4.9:1 is calculated for (TR1C + TR2): BT2;

- $\quad$ Based on the mean CPUE estimations, a mean transition factor of 5.1:1 is calculated for $($ TR1C + TR2): BT2;

- $\quad$ And based on the maximum CPUE estimations a maximum transition factor of 5.7:1 is calculated for (TR1C + TR2): BT2.

Table 9a. Range of estimation of the cod catch and the catch per unit of effort.

\begin{tabular}{c|ccccccccc}
\hline \multicolumn{2}{c}{} & landings & effort & Catch low & $\begin{array}{c}\text { Catch } \\
\text { mean }\end{array}$ & Catch high & CpUE low & CpUE mean & CpUE high \\
\hline BT1 & $\mathbf{9 1}$ & $\mathbf{1 2 0 4}$ & 91 & 92 & 93 & 0.075 & 0.076 & 0.077 \\
BT2 & $\mathbf{2 7 8}$ & $\mathbf{1 8 8 9 3}$ & 304 & 314 & 325 & 0.016 & 0.017 & 0.017 \\
TR1C & $\mathbf{8 5}$ & $\mathbf{7 8 2}$ & 86 & 92 & 99 & 0.109 & 0.118 & 0.126 \\
TR2 & $\mathbf{9 2}$ & $\mathbf{1 7 6 3}$ & 114 & 129 & 147 & 0.065 & 0.073 & 0.083 \\
\hline Total & $\mathbf{5 4 6}$ & $\mathbf{2 2 6 4 2}$ & 595 & 627 & 664 & 0.026 & 0.028 & 0.029 \\
\hline
\end{tabular}


Based on the estimated cod discard ranges (table 8), table 9b shows the estimated ranges of the total cod catch and the ranges of the CPUE in the different fleet segments when the vessels of the CCTV program are excluded. Based on these estimations of the cod catch:

- $\quad$ Based on the minimum CpUE estimations, a minimum transition factor of $4.2: 1$ is calculated for (TR1C + TR2): BT2;

- $\quad$ Based on the mean CPUE estimations, a mean transition factor of 4.4:1 is calculated for $($ TR1C + TR2): BT2;

- $\quad$ And based on the maximum CpUE estimations a maximum transition factor of 4.9:1 is calculated for (TR1C + TR2): BT2.

Table 9b. Range of estimation of the cod catch and the catch per unit of effort. Excluding vessels of the CCTV program

\begin{tabular}{|c|c|c|c|c|c|c|c|c|}
\hline & landings & effort & Catch low & $\begin{array}{l}\text { Catch } \\
\text { mean }\end{array}$ & Catch high & CpUE low & CpUE mean & CpUE high \\
\hline BT1 & 91 & 1204 & 91 & 92 & 93 & 0.075 & 0.076 & 0.077 \\
\hline BT2 & 277 & 18882 & 303 & 313 & 324 & 0.016 & 0.017 & 0.017 \\
\hline TR1C & 40 & 537 & 41 & 43 & 47 & 0.076 & 0.080 & 0.088 \\
\hline TR2 & 62 & 1203 & 77 & 87 & 99 & 0.064 & 0.072 & 0.082 \\
\hline Total & 470 & 21826 & 512 & 535 & 563 & 0.023 & 0.025 & 0.026 \\
\hline
\end{tabular}

\subsection{Percentage of cod avoidance trips}

Within the Cod Recovery Plan, fleet segments with low cod catches are subject to less rigid regulations. Therefore an overview is given of the average percentage landed cod in total landings and catch for the different TR gear types separately, aggregated gear types in fleet segments and all combined.

\subsubsection{Landings}

Table 10 shows -for each aggregation level- per quarter the total number of trips, the number and percentage of trips with $5 \%$ or less cod in the landings showing the percentage of 'cod avoidance trips'. The Fly_120+ has the lowest percentage (4\%) of cod avoidance trips. The Otter_70-99 and Fly_70-99 have the highest percentage of cod avoidance trips ( $96 \%$ and $95 \%$ respectively). On average $95 \%$ of the TR2 trips and $93 \%$ of the TR1C trips contain less than $5 \%$ cod in the landings.

Table 10. Percentage of TR trips with less than $5 \%$ cod in the landings per gear category

\begin{tabular}{|c|c|c|c|c|c|c|c|c|c|c|c|c|c|c|c|}
\hline & \multicolumn{5}{|c|}{$\mathrm{Nr}$ of fishing trips per gear category } & \multicolumn{5}{|c|}{$\mathrm{Nr}$ of trips with $5 \%$ cod or less } & \multicolumn{5}{|c|}{ Percentage $(\leq 5 \%$ Cod $)$} \\
\hline & Q1 & Q2 & Q3 & Q4 & 2016 & Q1 & Q2 & Q3 & Q4 & 2016 & Q1 & Q2 & Q3 & Q4 & 2016 \\
\hline \multicolumn{16}{|l|}{ Gear type } \\
\hline Fly_100-119 & 4 & 51 & 102 & 20 & 177 & 3 & 50 & 98 & 14 & 165 & 75 & 98 & 96 & 70 & 93 \\
\hline Fly_120+ & 0 & 8 & 54 & 21 & 83 & 0 & 1 & 1 & 1 & 3 & & 12 & 2 & 5 & 4 \\
\hline Fly_70-99 & 258 & 219 & 144 & 308 & 929 & 226 & 210 & 140 & 303 & 879 & 88 & 96 & 97 & 98 & 95 \\
\hline Otter_100-119 & 23 & 85 & 74 & 50 & 232 & 20 & 82 & 70 & 45 & 217 & 87 & 96 & 95 & 90 & 94 \\
\hline Otter_120+ & 82 & 38 & 16 & 2 & 138 & 4 & 23 & 15 & 2 & 44 & 5 & 61 & 94 & 100 & 32 \\
\hline Otter_70-99 & 126 & 176 & 182 & 157 & 641 & 113 & 164 & 181 & 156 & 614 & 90 & 93 & 99 & 99 & 96 \\
\hline \multicolumn{16}{|l|}{ Fleet segment } \\
\hline TR1AB & 82 & 45 & 70 & 23 & 220 & 4 & 24 & 16 & 3 & 47 & 5 & 53 & 23 & 13 & 21 \\
\hline TR1C & 27 & 136 & 176 & 70 & 409 & 23 & 132 & 168 & 59 & 382 & 85 & 97 & 95 & 84 & 93 \\
\hline TR2 & 384 & 394 & 326 & 465 & 1569 & 339 & 374 & 321 & 459 & 1493 & 88 & 95 & 98 & 99 & 95 \\
\hline All & 493 & 575 & 572 & 558 & 2198 & 366 & 530 & 505 & 521 & 1922 & 74 & 92 & 88 & 93 & 87 \\
\hline
\end{tabular}




\subsubsection{Catches}

In the Cod Recovery Plan, "cod avoidance trips" are defined as trips with $5 \%$ or less cod in the total catch. Above calculated percentages are based on landings data only. To estimate the percentages of actual cod avoidance trips, discards should be included. This includes discards of both cod and other (fish) species. As cod discards percentages (relative to total catch) are low compared with other species like dab, plaice and/or sole, the total proportion of cod in the total catch is likely lower than the proportion of cod landings in the total landings. Therefore, the calculated percentages of cod avoidance trips based on landings data is probably an underestimation.

Table 11 shows -for each aggregation level- per quarter the total number of trips, the number and percentage of trips with $5 \%$ or less cod in the catches. The following two assumptions underlie the numbers in table 11: first, the average estimation of cod discards, shown in table 8 , has been used. Second, total discards fraction, relative to the total catch, is similar for all gear types and is $40 \%$. This discard fraction estimate is chosen based on the results of the discards self-sampling program of Wageningen Marine Research (Reijden et al., 2014).

All cod landings are multiplied with the gear-specific cod discard ratio to estimate cod catches. All other landings are multiplied with an average discards ratio $(40 \%)$ to estimate total catch ratio. Then, a similar calculation has been performed as described in section 4.4.1. This resulted in a slightly higher percentage of cod avoidance trips, with $96 \%$ and $94 \%$ of the trips in the TR2 and TR1C fleet segments respectively.

Table 11. Percentage of TR trips with less than $5 \%$ cod in the catches per gear category, based on average cod discards estimations.

\begin{tabular}{|c|c|c|c|c|c|c|c|c|c|c|c|c|c|c|c|}
\hline & \multicolumn{5}{|c|}{ Nr of fishing trips } & \multicolumn{5}{|c|}{$\mathrm{Nr}$ of trips with $5 \%$ cod or less } & \multicolumn{5}{|c|}{ Percentage ( $\leq 5 \%$ Cod) } \\
\hline & Q1 & Q2 & Q3 & Q4 & 2016 & Q1 & Q2 & Q3 & Q4 & 2016 & Q1 & Q2 & Q3 & Q4 & 2016 \\
\hline \multicolumn{16}{|l|}{ Gear type } \\
\hline Fly_100-119 & 4 & 51 & 102 & 20 & 177 & 3 & 50 & 98 & 15 & 166 & 75 & 98 & 96 & 75 & 94 \\
\hline Fly_120+ & 0 & 8 & 54 & 21 & 83 & 0 & 1 & 1 & 1 & 3 & & 12 & 2 & 5 & 4 \\
\hline Fly_70-99 & 258 & 219 & 144 & 308 & 929 & 230 & 211 & 141 & 303 & 885 & 89 & 96 & 98 & 98 & 95 \\
\hline Otter_100-119 & 23 & 85 & 74 & 50 & 232 & 20 & 82 & 71 & 45 & 218 & 87 & 96 & 96 & 90 & 94 \\
\hline Otter_120+ & 82 & 38 & 16 & 2 & 138 & 4 & 23 & 16 & 2 & 45 & 5 & 61 & 100 & 100 & 33 \\
\hline Otter_70-99 & 126 & 176 & 182 & 157 & 641 & 113 & 166 & 181 & 156 & 616 & 90 & 94 & 99 & 99 & 96 \\
\hline \multicolumn{16}{|l|}{ Fleet segment } \\
\hline TR1AB & 82 & 45 & 70 & 23 & 220 & 4 & 24 & 17 & 3 & 48 & 5 & 53 & 24 & 13 & 22 \\
\hline TR1C & 27 & 136 & 176 & 70 & 409 & 23 & 132 & 169 & 60 & 384 & 85 & 97 & 96 & 86 & 94 \\
\hline TR2 & 384 & 394 & 326 & 465 & 1569 & 343 & 377 & 322 & 459 & 1501 & 89 & 96 & 99 & 99 & 96 \\
\hline All & 493 & 575 & 572 & 558 & 2198 & 370 & 533 & 508 & 522 & 1933 & 75 & 93 & 89 & 94 & 88 \\
\hline
\end{tabular}

\subsection{Comparison with previous years}

This report is the fifth in a series of cod monitoring reports (see Kraan et.al., 2013; Kraan et.al., 2014; Reijden et.al., 2015; Trapman \& Machiels 2016a). Table 12 presents an overview of the cod CpUE transition ratios of TR1C and TR2 on the one hand and the BT2 on the other hand. The table also presents the yearly LPUE or CPUE of the different fleet segments. The ratio over the year 2016 is lower than 2015 and closer to the earlier years.

Table 13 demonstrates the percentage of cod avoidance trips of the TR1C and the TR2 fleet segments during the years that the cod monitoring program has been running. 
As Kraan et.al. (2014) already suggested in 2014, the cod LpUE differs per year. Still it is poorly understood why. The variance analysis of Reijden et al. (2016) showed that there is no constant cod catchability within the different fleet segments. In order to better understand the differences in yearly LpUEs in the different fleet segments, time series of landings, in combination with time series of fishing locations, gear employment, cod abundance and interviews with fishermen may help to better understand the drivers behind these observed data.

Table 12: LpUE or CpUE in kg/ kW-day of the TR1C, TR2 and BT2 fleet segments and the (TR1C+TR2):BT2 transition ratio's over the years that the cod monitoring program has taken place.

\begin{tabular}{|l|lll|l|}
\hline Year & TR1C & TR2 & BT2 & (TR1C+TR2): BT2 CpUE ratio \\
\hline 2012 LpUE & 0.09 & 0.09 & 0.04 & $\begin{array}{l}>3 \text { (average based on different sources of } \\
\text { discard data), excluding CCTV vessels }\end{array}$ \\
\hline 2013 LpUE & 0.07 & 0.07 & 0.02 & $\begin{array}{l}3.1 \text { (average based on different sources of } \\
\text { discard data), excluding CCTV vessels }\end{array}$ \\
\hline 2014 CpUE & 0.16 & 0.10 & 0.03 & 3.7 (CpUE based on STECF data) \\
\hline 2015 CpUE & 0.10 & 0.17 & 0.02 & 7.6 (average CpUE) \\
\hline 2016 CpUe & 0.12 & 0.07 & 0.02 & 5.1 (average CpUE) \\
\hline & 0.09 & 0.08 & 0.02 & 4.4 (average CpUE) excluding CCTV vessels \\
\hline
\end{tabular}

Table 13: Percentages of cod avoidance trips of the TR1C and the TR2 fleet segments over the years that the cod monitoring program has taken place.

\begin{tabular}{|l|cc|}
\hline Year & Cod avoidance trips TR1C & Cod avoidance trips TR2 \\
\hline 2012 & $94 \%$ & $87 \%$ \\
\hline 2013 & $96 \%$ & $94 \%$ \\
\hline 2014 & $89 \%$ & $90 \%$ \\
\hline 2015 & $95 \%$ & $86 \%$ \\
\hline 2016 & $94 \%$ & $96 \%$ \\
\hline
\end{tabular}




\section{Discussion}

The conversion factor calculated in this report based on catches should be considered with caution. The reason for this is that the CPUE, on which the conversion factor is based, is itself a ratio. This is because total catch is based on landings plus an estimated level of discards, and hence, exact discard rates are unknown as catches are not fully documented nor monitored. The alternative, to calculate the conversion factor based on LpUE, would result in the problem that discards are not taken into account at all.

In this report we present not only the mean conversion factor based on $\mathrm{CpUE}$, but also a second one based on a smaller number of vessels. This second hasn't been presented earlier and is a result of excluding the 12 vessels participating in the CCTV program as was suggested in the report of last year (Trapman \& Machiels, 2016). The fleet that fishes with CCTV cameras on board to fully document cod catches are exempted from effort regulations. In addition these vessels receive $30 \%$ cod quota on top of their usual quota. This group of vessels consist of TR1A vessels (if mesh is $>120 \mathrm{~mm}$ ) but also of vessels with smaller mesh sizes (TR1C, TR2) (van Helmond, 2015). These vessels influence the CpUE level of the TR1C and TR2 fleet segment and thereby the conversion factor. This to the disadvantage of the other vessels in the TR1C and TR2 categories. Excluding them results in a lower conversion factor from 5.1 to 4.4. Both values for the conversion factor are in between the factors of 2014 and 2015. The factors of 2014 and 2015 would also reduce when the CCTV fleet had been excluded.

This will be the last report in this series, as in 2016 the European cod recovery plan has been revised. In this revision the rules on days at sea are abolished, because evaluations had shown that there were too many disadvantages related to these rules. Furthermore from 2017 onward cod in targeted fisheries will be part of the landing obligation, and from 2018 also in fisheries where cod is a bycatch. When this is the case, the rules on days at sea have no longer added value. 


\section{Conclusions}

This report provides an overview of the fishing activity, the cod catches and the cod landings per unit of effort of the various gear categories in the BT2 and the TR fleet segments during the year 2016. The Catch per Unit of Effort (CpUE) transition ratio between the BT2 and the TR1C plus TR2 fleet segments was calculated and the number of cod avoidance trips in the TR-fleet were calculated.

The CpUE effort transition ratio (TR1C+TR2): BT2 lies between 4.2:1 and 5.7:1, depending on whether the ratio is calculated on the basis of minimum or maximum STECF discard estimations respectively and in- or excluding vessel being part of the CCTV program. Based on average discard estimations including all vessels, the ratio is $5.1: 1$, this transition ratio is lower than in the last year, but higher than in the years 2012-2014.

The percentage of cod avoidance trips, fishing trips with $5 \%$ cod or less in the total catches, in the TR1C and the TR2 fleets were $94 \%$ and $96 \%$ respectively. These percentages are based on average cod discard estimations. When minimum or maximum discard estimations are used, the calculated percentages of cod avoidance trips does not vary more than 2 or $3 \%$ from the percentage based on average estimations. These percentages are comparable with those in earlier years. 


\section{Quality Assurance}

Wageningen Marine Research utilises an ISO 9001:2008 certified quality management system (certificate number: 187378-2015-AQ-NLD-RvA). This certificate is valid until 15 September 2018. The organisation has been certified since 27 February 2001. The certification was issued by DNV Certification B.V.

Furthermore, the chemical laboratory at IJmuiden has NEN-EN-ISO/IEC 17025:2005 accreditation for test laboratories with number L097. This accreditation is valid until $1^{\text {th }}$ of April 2021 and was first issued on 27 March 1997. Accreditation was granted by the Council for Accreditation. The chemical laboratory at IJmuiden has thus demonstrated its ability to provide valid results according a technically competent manner and to work according to the ISO 17025 standard. The scope (L097) of de accredited analytical methods can be found at the website of the Council for Accreditation (www.rva.nl).

On the basis of this accreditation, the quality characteristic $Q$ is awarded to the results of those components which are incorporated in the scope, provided they comply with all quality requirements. The quality characteristic $Q$ is stated in the tables with the results. If, the quality characteristic $Q$ is not mentioned, the reason why is explained.

The quality of the test methods is ensured in various ways. The accuracy of the analysis is regularly assessed by participation in inter-laboratory performance studies including those organized by QUASIMEME. If no inter-laboratory study is available, a second-level control is performed. In addition, a first-level control is performed for each series of measurements.

In addition to the line controls the following general quality controls are carried out:

- Blank research.

- Recovery.

- Internal standard

- Injection standard.

- Sensitivity.

The above controls are described in Wageningen Marine Research working instruction ISW 2.10.2.105. If desired, information regarding the performance characteristics of the analytical methods is available at the chemical laboratory at IJmuiden.

If the quality cannot be guaranteed, appropriate measures are taken. 


\section{References}

Hintzen, NT, A Coers and KG Hamon (2013) A collaborative approach to mapping value of fisheries resources in the North Sea (part 1: Methodology). IMARES report C001/13.

Kraak, S.B.M. et.al. (2013) Lessons for fisheries management from the EU cod recovery plan. Marine Policy 37: $200-2013$.

Kraan, ML, SS Uhlmann, MAM Machiels, HMJ van Overzee and ATM van Helmond (2013) Monitoring of cod catches in Dutch otter trawls and seines. IMARES report C077/13.

Kraan, ML, MAM Machiels, KJ van der Reijden and AJ Paijmans (2014) Monitoring of cod catches in Dutch otter trawls and seines. IMARES report C105/14.

Reijden, KJ van der, R Verkempynck, RR Nijman, SS Uhlmann, ATM van Helmond and A Coers (2014) Discards self-sampling of Dutch bottom-trawl and seine fisheries in 2013. CVO report 14.007.

Reijden, K.J. van der,; M.A.M. Machiels, B.K. Trapman and M.L. Kraan (2016) Monitoring cod catches of the Dutch demersal fleet in 2014. Investigating the effects of season and fishing gear on cod landings. IMARES Report C010/16.

Trapman BK and M.A.M. Machiels (2016a) Monitoring cod catches of the Dutch demersal fleet in 2015. Wageningen Marine Research, IJmuiden C106/16.

Trapman B.K. and M.A.M. Machiels (2016b). Cod monitoring : results 2016, quarter 1 . Wageningen Marine Research, IJmuiden C105/16.

van Helmond, A. T. M., C. Chen, B.K. Trapman, M. Kraan, \& J. J. Poos (2016). Changes in fishing behaviour of two fleets under fully documented catch quota management: Same rules, different outcomes. Marine Policy, 67, 118-129. 


\section{Justification}

Report C056/17

Project Number: 4318100117

The scientific quality of this report has been peer reviewed by a colleague scientist and a member of the Management Team of Wageningen Marine Research

Approved:

Dr. M.L. Kraan

Researcher

Signature:

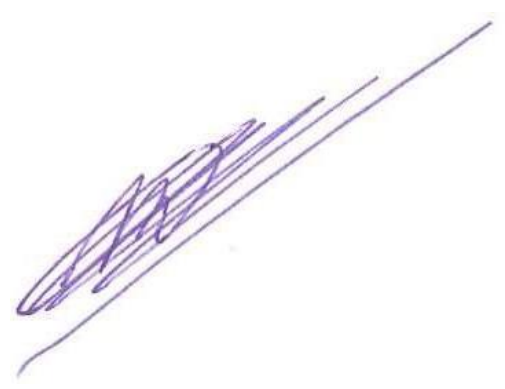

Date:

25 July 2017

Approved: Drs. J. Asjes

Manager integration

Signature:

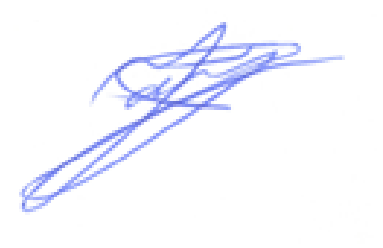

Date: 25 July 2017 


\section{Appendix A The EU Cod Recovery Plan}

Following serious depletion of Europe's four cod stocks ${ }^{1}$ in the early 2000s, the EU member states agreed to develop a plan to recover the cod stocks. Following short-term recovery plans from 2001 and 2002, the first long-term cod recovery plan was agreed upon in 2004, laid down in Regulation (EC) 423/2004. This long-term plan included a top down prescribed approach to reach biomass targets for all four stocks, and a schedule to reduce days at sea. In the run up to the reform of the Common Fisheries Policy (CFP) in 2002, ideas of more participatory fisheries management and differentiated implementation in different regions had gained popularity in the EU. Recognizing this shift in ideas about fisheries management and in light of the limited improvement of the cod stocks following the first cod recovery plan, a second cod recovery plan was agreed upon in 2008 (Kraak et al., 2013).

This second cod recovery plan, laid down in Regulation (EC) $1342 / 2008$, entered into force in January 2009. It had the objective to ensure sustainable exploitation of the cod stocks on the basis of maximum sustainable yield. The second cod recovery plan sets rules about setting Total Allowable Catches (TACs) and effort restrictions. Yearly effort reductions will be based on the same percentage as specified by the fishing effort (F) used in the estimations of TAC.

Through article 11 and 13 it encourages nationally developed plans for the reduction of cod catches. Article 11 allows member states to request exemption from the effort regime for groups of vessels that of which total cod catches do not exceed $1,5 \%$ of the total catch of the group. Article 13 allows members states to allocate additional effort within groups in case of the use of highly selective gear or if cod is avoided, resulting in a maximum of $5 \%$ cod per fishing trip. The implementation of these articles were delegated to Member States and industry (Kraak et al., 2013).

Table A1. Gear groups as distinguished in the European Cod Recovery Plan

\begin{tabular}{c|ccc}
\hline & Fleet definition & Gear type & Mesh size in mm \\
\hline 1. & TR1 & Bottom trawls and seines & $>100$ \\
2. & TR2 & Bottom trawls and seines & $70-99$ \\
3. & TR3 & Bottom trawls and seines & $16-31$ \\
4. & BT1 & Beam trawls & $>120$ \\
5. & BT2 & Beam trawls & $80-119$ \\
6. & GN & Gill nets & \\
7. & GT & Trammel nets & \\
8. & LL & Longlines &
\end{tabular}

Fishing effort, in kW-days, was allocated to different gear categories within Member States based on track records over the years 2004 till 2006 (Website Visned, 2009). Transfer of effort between gear groups is permitted according to art. 17, provided that Member States provide the commission with information of the cod CPUE of the donor gear group and the receiving gear group. When the CpUE of the receiving group is higher, the transfer of the effort occurs on the basis of a correction factor (STECF, 2001). A standard correction factor is calculated by STECF. If the correction factor calculated for an individual Member State differs by more than $15 \%$ from STECF's correction factor, Member States can apply at the European Commission for national transfer rates (ibid.).

\footnotetext{
${ }^{1}$ In the geographical areas of the Kattegat, the North Sea including the Skagerrak and the Eastern Channel, West of Scotland and the Irish Sea.
} 


\section{Appendix B The Dutch Cod Avoidance Plan}

Around the time the second cod avoidance plan was approved, an increasing number of Dutch skippers switched from the beam trawl gear to twinrig and flyshoot gears. They (mainly) did this to reduce fuel consumption, as the latter fishing methods require less fuel. This meant that the number of vessels in the TR category increased and the number of vessels in the BT category decreased, while effort allocation to the two groups did not change. This gradually resulted in a shortage of days in the BT2 fleet and a difficulty for the skippers in the TR-fleet, who did not have sufficient days at sea. In 2012 for instance, to get one day extra for the TR1 fleet, 16 BT2 days were needed, and for getting an extra day in the TR2 fleet, 5 BT2 days were needed. From 2011 onwards, the Dutch government got permission from the EC to distinguish between TR1A and TR1B as a cod directed fishery and TR1C as cod-as-bycatch fishery. Also the TR2 fleet was classified as cod-as-bycatch fishery. The difference between TR1A and TR1B was that TR1A participated in a fully documented fisheries project, meaning that they had a camera on board to monitor all cod catches. For transferring effort from BT2 to TR1C and TR2, a correction factor of $3: 1$ was permitted.

To compensate for this specific Dutch regulation, extra measures were agreed upon in consultation with the Dutch fishing industry. These extra measures included additional technical measures, seasonal closures (RTC's) and cooperation of the fleet in cod CpUE related data collection about catch compositions (Ministry of Economic Affairs, Agriculture and Innovation, 2012).

The British and the Dutch governments have agreed to close nine areas every month where vessels in the gear categories TR1 and TR2 (otter trawl, twinrig and flyshoot) are not allowed to fish (Website Vissersbond, n.d.). The areas, referred to as Real Time Closures are 1/16 share of an ICES rectangle in size, and they are closed with the intention to reduce Cod catches. The location of the RTC is based on cod CPUE of the previous year during the same month. The RTC's are not closed for the Belgian and German TR-fleets who have no interest in the lowered conversion factor (Visserijnieuws, 2015). Besides these RTC's, seasonal closures are implemented for certain areas from January until May in order to protect spawning and juvenile cod (Website Vissersbond, 2015). 


\section{Appendix C Extended Materials and Methods}

The method used in this report is consistent with the method described in Hintzen et al. 2013.

\section{Data pre-processing}

VMS and logbook data were received from the Ministry of Economic Affairs and stored in a local database at Wageningen Marine Research.

VMS records are considered invalid and are therefore removed from the analyses if they :

o Are duplicates or pseudo-duplicates (indication of malfunctioning of VMS device)

o Identify an invalid geographical position

o Are located in a harbour

o Are located on land

o Are associated with vessel speeds $>20$ knots

Logbook records are removed from the analyses when they:

o Are duplicates

o Have arrival date-times before departure date-times

o Overlap with other trips of that vessel

\section{Link VMS and logbook data}

VMS and logbook datasets are linked using the unique vessel identifier and date-time stamp in both datasets available. In other words, records in the VMS dataset that fall within the departure-arrival timeframe of a trip described in the logbook are assigned the unique trip number from the logbook record which allows matching both datasets. The following gear types were selected as TR gear: OTB (Otter bottom trawls), OTT (Otter Twin Trawls), PTB (Pair Bottom Trawls), SDN (Danish Seine), SSC (Scottish Seines), SPR (Pair Seine). All TR gears are further divided based on their mesh size, following TR1AB: > =120mm, TR1C: $100-119 \mathrm{~mm}$, TR2: <100mm. The BT gear is defined as TBB (Beam Trawls) gear type. This consists not only of the traditional beam trawl; all innovative sub-gears like sumwing, pulse and pulswing are included in the BT gear. Next, the BT gear is further classified into categories, based on mesh size. The used geartype BT2 includes all BT vessels operating with a mesh size of $70-99 \mathrm{~mm}$.

\section{Spatial distribution}

The fishing activity determined from the logbooks (kW-days) and the cod landings recorded in the logbooks $(\mathrm{kg})$, are assigned to those (fishing) VMS records that have vessel id, fishing date, and fishing position in common. At the spatial scale of $1 / 4$ degree longitude* $1 / 8$ degree latitude (1/16 ICES rectangle), the total landings of cod $(\mathrm{kg})$ and fishing activity ( $\mathrm{kW}$-days) are calculated. Subsequently LpUE (landings per unit of effort) can be calculated for each $1 / 16$ ICES rectangle by dividing the landings by the activity. 
Wageningen Marine Research

T +31 (0)317480900

E: marine-research@wur.nl

www.wur.eu/marine-research

Visitors' address

- Ankerpark 271781 AG Den Helder

- Korringaweg 5, 4401 NT Yerseke

- Haringkade 1, 1976 CP IJmuiden
Wageningen Marine Research is the Netherlands research institute established to provide the scientific support that is essential for developing policies and innovation in respect of the marine environment, fishery activities, aquaculture and the maritime sector.

\section{Wageningen University \& Research:}

is specialised in the domain of healthy food and living environment.

\section{The Wageningen Marine Research vision}

'To explore the potential of marine nature to improve the quality of life'

\section{The Wageningen Marine Research mission}

- To conduct research with the aim of acquiring knowledge and offering advice on the sustainable management and use of marine and coastal areas.

- Wageningen Marine Research is an independent, leading scientific research institute

Wageningen Marine Research is part of the international knowledge organisation Wageningen UR (University \& Research centre). Within Wageningen UR, nine specialised research institutes of the Stichting Wageningen Research Foundation have joined forces with Wageningen University to help answer the most important questions in the domain of healthy food and living environment. 